\title{
Educational Management Using E-Learning to Maximize Learning Efficiency and Speed Up the Industrial Revolution 4.0
}

\author{
Ahmad Qurtubi ${ }^{1}$ \\ DOI:10.35445/alishlah.v13i3.856
}

\begin{tabular}{l} 
Article Info \\
\hline Keywords: \\
Education management; \\
E-learning; \\
Acceleration; \\
Industrial revolution 4.o; \\
Policy
\end{tabular}

Kata kunci:

Manajemen pengelolaan Pendidikan;

E-learning;

Akselerasi;

Revolusi industri 4.O;

Kebijakan

\begin{abstract}
Education is the key to increasing the quality of human resources. The rapid development of information technology has necessitated a shift in the educational paradigm. Based on the study of education policy, this study aims to determine how e-learning management can be used to achieve the effectiveness and acceleration of learning in today's 4.0 revolution era. This study uses a literature review as a method of data collection. Indonesia's e-learning policies are not clearly defined by law, according to the findings of an investigation.
\end{abstract}

\begin{abstract}
Abstrak
Peningkatan kualitas sumber daya manusia dilakukan dengan meningkatkan kualitas pendidikan. Terkait dengan perkembangan teknologi informasi yang kian pesat, pendidikan kini harus beradaptasi dengan teknologi. Penelitian ini bertujuan untuk mengetahui manajemen pengelolaan pendidikan yang berbasis elearning dalam mewujudkan efektifitas dan akselerasi pembelajaran di era revolusi 4.0 dengan studi kebijakan pendidikan oleh pemeritah. Pendekatan yang digunakan pada penelitian ini adalah kualitatif dengan jenis studi literatur. Dari hasil analisis yang telah dilakukan didapatkan hasil bahwa belum adanya peraturan perundang-undangan yang jelas tentang kebijakan e-learning di Indonesia.
\end{abstract}

\section{INTRODUCTION}

Each era of government impacts changes and improvements in various sectors that lead to the formulation of policies. In principle, policies are made by the government to regulate and tidy up the order of various sectors and fields, to realize the noble ideals of the nation that always follows the progress of the times without destroying the noble values of culture (Octofrezi, 2020). One of the important policies is education policy. In the current era of Joko Widodo's government, there is a policy on readiness to face the Industrial Revolution 4.0 era (Maemunah, 2018). Several efforts have been made to make the world of education able to catch up and adapt to the needs of industry 4.o. The Indonesian government has set a strategic step to face the industrial revolution 4.0 by compiling a roadmap for Making Indonesia 4.o. One of the visions of the Making Indonesia 4.0 roadmap is to make Indonesia one of the top 10 countries with the strongest economy in the world by 2030. Improving the

\footnotetext{
${ }^{1}$ UIN Sultan Maulana Hasanuddin Banten

Email: ahmad.qurtubi@uinbanten.ac.id 
quality of human resources is one of the priorities in the "Making Indonesia 4.0" roadmap (Nia Safitri, 2019).

Education is the key to increasing the quality of human resources. The rapid development of information technology has necessitated a shift in the educational paradigm. It incorporates information technology into teaching and learning activities (Yanzi et al., 2019). e-learning is a manifestation of the use of information technology in education. E-learning is defined as a method of teaching and learning that does not necessitate face-to-face interaction between students and teachers. Assuming this is correct, e-learning will be a popular alternative to face-to-face instruction in the future because it allows teachers and students to continue the learning process without physically meeting (Simanihuruk et al., 2019).

In Indonesia, e-learning is advancing rapidly, thanks to initiatives from the government, the private sector, and educational institutions working on their own. Universities in Indonesia are well aware of the importance of e-learning in their educational programs (Wijaya et al., 2016). Specifically, this has to do with the policy that grants universities control over the delivery of distance learning (PJJ). Minister of Education and Culture Number 109 of 2013 on the Implementation of Distance Education in Higher Education was the driving force behind this change. Thus, universities began to offer distance education in various ways based on this policy (Widayati, 2020). Educational policy is a set of rules as a form of government alignment to build an education system according to the shared goals and objectives (Sugianti et al., 2020). Education policy is part of the scope of public policy. This public policy involves government intervention in its manner and authority. Education is an integral part of public policy. For example, the Indonesian government implements a five-day school policy, a policy to abolish the National Examination, a single tuition fee (UKT) policy, an accreditation certification policy and so on (Yanti, 2020).

Currently, the industrial revolution is entering its fourth phase. The Industrial Revolution 4.0 was marked by the development of the internet of things, followed by new data science, artificial intelligence, robotics, cloud, 3D printing, and nanotechnology (Ghufron, 2018). Education theorists often refer to Education in the Industrial Revolution Era 4.0 to describe various ways of integrating cyber technology both physically and non-physically in learning. Education in the Industrial Revolution Era 4.0 is a phenomenon that responds to the needs of the industrial revolution by adjusting the new curriculum according to the current situation. The curriculum is able to open a window of the world through the hand, for example, using the internet of things (IOT). On the other hand, teachers also get more references and teaching methods (Retnaningsih, 2019).

In 2018, President Joko Widodo launched the "Making Indonesia 4.0" movement, which is the government's commitment to enter this era of the industrial revolution 4.o. Several parties revealed that the world of education in Indonesia also needs to prepare to enter this 4.0 revolution by making several changes in implementing learning methods in schools. First, the fundamental thing is to change the nature and mindset of students. Secondly, be able to hone and develop children's talents and institutions. Education must change the learning model according to the needs of the times.

E-learning was first popularized by the University of Illinois at Urbana-Champaign in 1960 with a Computer Based Training (CBT) program called PLATO (Programmed Logic for Automated Teaching Operation). A previous study (Edy, 2011) related to e-learning-based learning and its application shows that e-learning has a positive and significant effect on learning motivation. Besides, the level of utilization of e-learning has a positive and significant effect on individual performance in vocational students. In addition, based on Sukamto (2012) research, the number of students satisfaction was $86 \%$ who understood the e-learning learning system at the Department of Electrical Engineering, Semarang State Polytechnic in the Web-based Computer Network Course and Mobile Application (Sukamto \& Anggara, 2012). At this time, e-learning conveys information to students in one direction (Simanihuruk et al., 2019). The scope written in this research refers to the National Education Strategic Plan 20202024, namely Improving the quality of Indonesian people, where one of the strategies is to improve the quality of teaching and learning. 


\section{METHOD}

This research is a type of library research. The data studied came from books, theses, journal articles and other sources relevant to the research theme, namely education policy (Sari, 2020). Researchers look for and examine data sourced from various literature, books that discuss approaches in Jokowi's education era. In order to obtain the expected data in this research, the data collection technique used is the documentation technique. The procedures include collecting, compiling, and digging up written or printed data such as books, journal articles, or thesis themed on politics and national education policies. Then it is equipped with electronic data in the form of government websites, online news, articles when collecting any policy products of the reform era, both national policies that are constantly changing, dynamic from period to period of leadership. Second, the authors combine these data sets into a single data set outlined in the research results (Maisaro et al., 2018).

The data analysis technique used is content analysis, which analyzes any changes in the form of education policy and the content of legal products made by the government in the reform era. Of course, each policy made by the leadership is different and changes according to the context of the needs and socio-political dynamics (Sugiyono, 2015).

\section{FINDING AND DISCUSSION}

\section{Education Policy in the Era of Joko Widodo's Administration}

In the era of President Joko Widodo (Jokowi), his government has set several policies within a decade. Most of them continue the policies that have been implemented in the previous era, namely the era of President Susilo Bambang Yudhoyono (Noermanzah et al., 2017). The rest are new policies. These policies are:

a. National examination is not a determinant of graduation

b. The Transition of the National Examination to a Computer-Based National Examination (UNBK)

c. Implementation of the 2013 Curriculum (K-13) as a whole

d. Determination of National Santri Day

e. Teachers at the forefront of the $3 \mathrm{~T}$ area (Front, Remote, and Disadvantaged)

f. Smart Indonesia Card (KIP)

g. PPDB Zoning System (New Student Admission)

h. Strengthening Character Education (PPK)

i. The existence of Teacher Professional Education (PPG)

j. HOTS concept in learning and making exam questions

k. Freedom to Learn

\section{Legal Products in the Era of Jokowi's Administration}

The administration of President Jokowi produced several legal products related to education both by the details of the above and other policies (Sabri, 2019), namely:

1. PP No. 32 of 2013 concerning Amendments to Government Regulation Number 19 of 2005 concerning National Education Standards.

2. PP No. 13 of 2015 concerning the Second Amendment to Government Regulation Number 19 of 2005 concerning National Education Standards.

3. Permendikbud No. 80 of 2015 concerning the Prevention and Overcoming of Violence in Schools.

4. Permendikbud Number 19 of 2016 concerning the Smart Indonesia Program.

5. Permendikbud No. 20, 21, 22, and 23 of 2016 concerning Graduate Competency Standards, Content Standards, Process Standards, and Assessment Standards.

6. PP No. 87 of 2017 concerning Strengthening Character Education.

7. PP No. 46 of 2019 concerning Religious Higher Education.

8. Permendikbud No. 11 of 2018 concerning Organization and Work Procedure of the Ministry of Education and Culture. 
9. Permendikbud No. 6 of 2019 concerning Organizational Guidelines and Work Procedures for Primary and Secondary Education Units.

10.Permendikbud No. 20 of 2019 concerning Amendments to Permendikbud 51 of 2018 concerning PPDB.

\section{Application of Learning Management in Indonesia}

The implementation of e-learning in Indonesia requires legal policy support so that the various efforts made have a strong legal and policy basis. The closest e-learning-related policy is the Regulation of the Minister of Education and Culture of the Republic of Indonesia Number 109 of 2013 concerning the Implementation of Distance Education in Higher Education. The policy is more specific in regulating the implementation of distance education at the tertiary level. Meanwhile, there is no more specific policy governing this (Siron et al., 2020).

The challenge of implementing e-learning in Indonesia is in the policy aspect, namely formulating policies for implementing e-learning at various levels of formal education in Indonesia. The policy should become a strong and adequate legal umbrella in the effort to implement e-learning in educational institutions in Indonesia (Bulić et al., 2017). Thus educational institutions will be more confident in implementing e-learning-based learning programs planned or have already been done. With the regulation that regulates this, the implementation of learning with e-learning can be aligned with face-to-face learning in conventional classes.

E-learning technology-based learning is carried out by human resources who have sufficient capacity. Human resources are both subject and object in learning using e-learning. The active role of human resources is an important factor in implementing effective learning with e-learning. The challenge of developing quality human resources is a prerequisite in implementing e-learning. Mastery of technology is an absolute thing that must be mastered by individuals and groups who will use elearning. This is because all e-learning activities use technological innovations in hardware and software. Without mastery of technology, especially computers and the internet, the use of e-learning will experience obstacles (Widodo et al., 2021).

Implementing e-learning outside of the technical activities of developing an e-learning system involves at least 2 (two) actors, namely the teacher and the learner. Teachers have a role in the implementation of e-learning. As with face-to-face learning in class, teachers must provide learning materials optimally but with different media, namely e-learning. Therefore, the teacher's understanding of the technical use of e-learning must be mature so that during the learning process, the teacher is not confused in using e-learning (Wahyudi, 2017). Intensive, periodic and continuous training for teachers regarding e-learning must be carried out. Moreover, as a system that continues to grow, e-learning will inevitably experience changes in feature development and stages of use as it relates to the needs and developments of information technology. The next actor who plays a role in the implementation of elearning is the learner. As e-learning users take advantage of the knowledge available on these media, the learner has to master e-learning well (Al-Fraihat et al., 2020). However, today's young generation is very familiar with technology such as computers, the internet and applications, the psychological development of learners by providing motivation, self-discipline and emotions.

Infrastructure is the next challenge that must be seriously studied in e-learning implementation efforts. Adequate infrastructure is the optimal support for the implementation of e-learning because this learning method relies heavily on infrastructure. Good infrastructure is needed at every stage of elearning implementation, from the development stage to implementation and even evaluation (Hayati, 2020). The e-learning system is designed on a quality infrastructure that meets good standards. Romy $\mathrm{S}$ Wahono explained the components that makeup e-learning, among others, as follows:

a. E-learning infrastructure in the form of computers, internet networks, multimedia equipment.

b. E-learning systems and applications are software systems that virtualize conventional teaching and learning processes, including classroom management, material creation, discussion forums, assessment systems, online exam systems and others.

c. E-learning content in the form of multimedia-based content and text-based content. 
Strategically, aspects of commitment and integrity must be addressed in addition to infrastructure and Human Resources (HR). This has to do with the long-term viability of the educational institution's e-learning implementation program (Nuryadin, 2017). If e-learning providers aren't fully committed to the program's long-term viability, the existence of legal policies, qualified human resources, and adequate infrastructure won't have any effect. To ensure that e-learning is implemented in a serious, optimal, and long-term manner, it's important that everyone involved commits to using it seriously and doing so with integrity.

When it comes to educational technology, it is widely accepted that using e-learning in the classroom has a positive and significant impact on student learning (Suharyanto and Adele, 2016). (Suharyanto \& Mailangkay, 2016). A study by Irawan, Susanti Triyanto, and Triyanto (2015) found that the e-learning system used by students and teachers at SMK Mambaul Falah Kudus can be used as an appropriate design in developing better teaching and learning methods because of the level of flexibility that allows teaching and learning activities to be carried out anywhere and at any time (Irawan et al., 2015). An investigation of the Directorate of Diploma Programs - IPB by Budi (2012) has shown that students, lecturers, and the entire academic community can benefit from the use of e-learning as an alternative learning method because it has been found to be both effective in implementation and efficient in terms of both implementation and evaluation of learning (Nurjayanti, 2012).

\section{CONCLUSION}

The industrial era 4.0 that we are currently living in requires the world of education to be capable of producing a quality next generation that meets contemporary demands. The integration of digital technology into e-learning is a strategic move toward accelerating Indonesia's educational progress. Elearning has the potential to significantly reduce the distance, time, and cost associated with conducting face-to-face learning in traditional classrooms. The various facilities provided by e-learning provide an opportunity for education in Indonesia to accommodate electronic-based learning. E-learning faces significant implementation challenges. It begins with hospitable policies, adequate human resources, adequate infrastructure, and commitment and integrity in program implementation. As a result, it is critical to take all aspects of education seriously in order to synergize in achieving educational acceleration in the 4.0 industrial revolution era through the use of e-learning. Additionally, a legal framework is required to govern e-learning-based learning policies in Indonesia, not just at the tertiary level, but also in primary and secondary education.

\section{REFERENCES}

Al-Fraihat, D., Joy, M., Masa'deh, R., \& Sinclair, J. (2020). Evaluating E-learning systems success: An empirical study. Computers in Human Behavior. https://doi.org/10.1016/j.chb.2019.08.004

Bulić, M., Jelaska, I., \& Mandić Jelaska, P. (2017). The Effect of E-learning on Adoption of Learning Outcomes in Teaching Science and Biology. Croatian Journal of Education - Hrvatski Časopis Za Odgoj i Obrazovanje. https://doi.org/10.15516/cje.v19i2.2230

David, F. R., David, F. R., \& David, M. E. (2016). Benefits , Characteristics , Components , and Examples of Customer-Oriented Mission Statements. International Journal of Business, Marketing, and Decision Sciences.

Edy, I. C. (2017). STUDI Pemanfaatan Web Site E-Learning Dan Pengaruhnya Terhadap Motivasi, Kinerja Dan Hasil Belajar Pada Guru Dan Siswa Smk Di Provinsi Jawa Tengah. Journal of Chemical Information and Modeling.

Elyana, L. (2019). Pengelolaan PAUD Berbasis Good School Governance. Journal of Curriculum Indonesia.

Fauzan Wakila, Y. (2021). Konsep dan Fungsi Manajemen Pendidikan. Equivalent : Jurnal Ilmiah Sosial Teknologi. https://doi.org/10.46799/jequi.v3i1.33

Ghufron, G. (2018). Revolusi Industri 4.0: Tantangan, Peluang, Dan Solusi Bagi Dunia Pendidikan. Seminar Nasional Dan Diskusi Panel Multidisiplin Hasil Penelitian Dan Pengabdian Kepada Masyarakat 2018. 
Hayati, N. (2020). Metode Pembelajaran Daring / E-Learning. Journal of Ganesha University.

Irawan, Y., Susanti, N., \& Triyanto, W. A. (2015). ANALISA DAN PERANCANGAN SISTEM PEMBELAJARAN ONLINE (E-LEARNING) PADA SMK MAMBAUL FALAH KUDUS. Simetris : Jurnal Teknik Mesin, Elektro Dan Ilmu Komputer. https://doi.org/10.24176/simet.v6i2.471

Maemunah. (2018). Kebijakan pendidikan pada era revolusi industri 4.0. Prosiding Seminar Nasional Pengambdian 2018 Univeristas Muslim Nusantara Al-Washliyah.

Maisaro, A., Wiyono, B. B., \& Arifin, I. (2018). Manajemen Program Penguatan Pendidikan Karakter Di Sekolah Dasar. Jurnal Administrasi Dan Manajemen Pendidikan. https://doi.org/10.17977/um027v1i32018p302

Maudiarti, S. (2018). Penerapan E-Learning Di Perguruan Tinggi. Perspektif Ilmu Pendidikan. https://doi.org/10.21009/pip.321.7

Muzammil, A. (2016). Kebijakan Pemerintah Dalam Bidang Pendidikan Dari Orde Lama Sampai Orde Baru (Suatu Tinjauan Historis). POTENSIA: Jurnal Kependidikan Islam. https://doi.org/10.24014/potensia.v2i2.2537

Nia Safitri. (2019). Pendidikan Indonesia Menyongsong Era Revolusi 4.o. Www.Kompasiana.Com.

Noermanzah, N., Emzir, E., \& Lustyantie, N. (2017). Variety Of Rhetorics In Political Speech President Of The Republic Of Indonesia Susilo Bambang Yudhoyono And Joko Widodo In Educational Field. Humanus. https://doi.org/10.24036/humanus.v16i2.8103

Nurdiyansyah, Widodo, A. (2017). Manajemen Sekolah Berbasis iCT. In The British Journal of Psychiatry.

Nurjayanti, B. dan B. (2012). Pengembangan Metode Pembelajaran Online Berbasis E-learning. Jurnal Sains Terapan.

NURYADIN, N. (2017). Strategi Pendidikan Islam Di Era Digital. FITRAH:Jurnal Kajian Ilmu-Ilmu Keislaman. https://doi.org/10.24952/fitrah.v3i1.637

Octofrezi, P. (2020). Menakar Kebijakan Pendidikan Nasional dan Pendidikan Islam di Indonesia Era Reformasi (Presiden Habibie dampai Presiden Jokowi Jilid I). Al-Fahim: Jurnal Manajemen Pendidikan Islam.

Retnaningsih, D. (2019). Tantangan dan Strategi Guru di Era Revolusi Industri 4.0 dalam Meningkatkan Kualitas Pendidikan. Prosiding Seminar Nasional: Kebijakan Dan Pengembangan Pendidikan Di Era Revolusi Industri 4.o.

Sabandi, Ahmad. Dewi Putri, A. (2019). Pengaruh Sistem Informasi Manajemen Pendidikan dan Kebutuhan Informasi Manajemen Program Sarjana Reguler PTN Terhadap Informasi Manajemen Pendidikan. Jurnal Sosiohumaniora.

Sabri, I. (2019). Peran Pendidikan Seni Di Era Society 5 . o untuk Revolusi Industri 4.o. Seminar Nasional Pascasarjana 2019.

Sari, M. (2020). Penelitian Kepustakaan (Library Research) dalam Penelitian Pendidikan IPA. Natural Science: Jurnal Penelitian Bidang IPA Dan Pendidikan IPA.

Simanihuruk, L., Simarmata, J., Sudirman, A., Hasibuan, M. S., Safitri, M., Sulaiman, O. K., Ramadhani, R., \& Sahir, S. H. (2019). E-Learning: Implementasi, Strategi dan Inovasinya. In Yayasan Kita Menulis.

Siron, Y., Wibowo, A., \& Narmaditya, B. S. (2020). Factors Affecting The Adoption Of E-Learning In Indonesia: Lesson From Covid-19. Journal of Technology and Science Education. https://doi.org/10.3926/jotse.1025

Sugianti, S., Santi, S., \& Rositah, R. (2020). Analisis kebijakan pendidikan terkait penerapan muatan lokal dan keterampilan sebagai mata pelajaran. Mappesona.

Sugiyono. (2015). Metode Penelitian Pendidikan Pendekatan Kuantitatif, Kualitatif, dan R\&D. Alfabeta.

Suharyanto, \& Mailangkay, adele B. L. (2016). Penerapan E-Learning Sebagai Alat Bantu Mengajar Dalam Dunia Pendidikan. Jurnal Ilmiah Widya. https://doi.org/10.1016/j.neubiorev.2016.02.001

Suhirman. (2016). Eksistensi Teknologi Pendidikan dalam Inovasi Pembelajaran. Jurnal Studi Islam Dan Kemasyarakatan.

Sukamto, \& Anggara, B. C. (2012). E-learning Jaringan Komputer Berbasis Web dan Aplikasi Mobile. Jurnal Teknik Elektro.

Wahyudi, I. (2017). Pengembangan Program Pembelajaran Fisika SMA Berbasis E-Learning dengan Schoology. Jurnal Ilmiah Pendidikan Fisika Al-Biruni. https://doi.org/10.24042/jipfalbiruni.v6i2.1850 
Widayati, S. (2020). Respon Mahasiswa Pada Proses Pembelajaran Mata Kuliah Daring. Child Education Journal.

Widodo, A., Ermiana, I., \& Erfan, M. (2021). Emergency Online Learning: How Are Students' Perceptions? https://doi.org/10.2991/assehr.k.201230.116

Wijaya, E. Y., Sudjimat, D. A., \& Nyoto, A. (2016). Transformasi pendidikan abad 21 sebagai tuntutan pengembangan sumber daya manusia di era global. Prosiding Seminar Nasional Pendidikan Matematika 2016.

Yanti, S. (2020). Analisis Kebijakan Pendidikan. Lentera: Indonesian Journal of Multidisciplinary Islamic Studies. https://doi.org/10.32505/lentera.v1i1.1662

Yanzi, H., Adha, M. M., Hidayat, O. T., \& Putri, D. S. (2019). Urgensi Nilai-Nilai Pancasila sebagai Dasar Pengembangan IPTEK Untuk Merespon Revolusi Industri 4.o. Repository.Lppm.Unila.Ac.Id. 
Al- Ishlah: Jurnal Pendidikan, December 2021, vol 13 (3), Pages 2319-2326

Ahmad Qurtubi

This page is intentionally left blank 